\title{
RELATIONSHIP OF THE HEALTH DEPARTMENT TO THE ENVIRONMENT PROTECTION AUTHORITY
}

$\mathbf{T}$

he NSW Health Department and the State Pollution

Control Commission (SPCC) enjoyed a close relationship for years and the Department continues such an association with the newly formed Environment Protection Authority (EPA). The Chief Health Officer was a commissioner of the SPCC but no Health appointment was made to the board of the new authority. Nevertheless, the Department maintains its representation on an important statutory committee of the EPA, the Hazardous Chemicals Advisory Committee (HCAC) and its sub-committees.

One sub-committee regularly reviews chemicals assessed by the National Industrial Chemicals Notification and Assessment Scheme and has a Health Department member.

Other matters receiving the attention of the HCAC include the 'rehabilitation' of cattle dip sites (the coordinating responsibility for which rests with the Department of Agriculture), standards for the development of other contaminated lands, pesticide storage, waste management and chemical incidents.

The Radiation Advisory Council (previously the Radiological Advisory Council) has been transferred to the EPA from the Health Department, together with administrative responsibility for the Radiation Control Act and Regulations.

The bulk of the council's functions has involved regulating the use of irradiating industrial, diagnostic and therapeutic apparatus and radionuclides, but the legislation now includes non-ionising radiation regulations.

The Ocean Outfalls Environmental Monitoring Program continues as a function of the EPA with Health input.

In the sphere of air pollution the Metropolitan Air Quality Study is managed by the EPA, with parallel health studies being undertaken by the NSW Health Department in an attempt to ascertain the relationship between air pollution and human sickness in Sydney.

EPA and Health Department representatives meet on a number of committees chaired by authorities other than the EPA. The following Health Department committees include EPA employees:

- Poisons Advisory Committee which deals with pharmaceuticals, industrial chemicals that are accepted carcinogens, and agricultural and veterinary chemicals which are included in the schedules of the Poisons Act; and
Pesticides Advisory Committee which was set up to advise the Deputy Chief Health Officer on pesticide issues.

The complexity of environmental pollution and its regulation is obvious to all engaged in 'environmental health' and numerous scientific disciplines and authorities must be called on for investigation and regulation in an attempt to control the environment.

The following are committees and groups which, although set up by other agencies, include the Health Department and the EPA:

- NSW Recycled Water Coordination Committee

(Public Works Department);

Consumer Products Safety Committee (Department of Consumer Affairs);

State Algal Coordinating Committee (Department of Water Resources);

Site Remediation Task Force for the Homebush Bay Development Project (Property Services Group); Woodsreef Asbestos Mine Site Rehabilitation Committee (Department of Mineral Resources); Malabar and North Head Sewage Treatment Works Incinerators' Study Group (Water Board); Interdepartmental Committee on Climate Change (Cabinet Office);

Interdepartmental Committee on Residues in Fish (Department of Fisheries);

Agriculture Minister's Advisory Committee on Agricultural and Veterinary Chemicals (Department of Agriculture); and

- Hazardous Materials Policy Coordinating Committee which has recently been formed to follow up the recommendations of the NSW Chemical Inquiry (Department of Planning).

Many of the agencies have local representatives in Health Areas and Regions. It is advantageous to Public Health Units to make and maintain contact with these representatives so local issues may be handled.

Chemical matters requiring central resolution or advice should be referred to the Toxicology Unit, NSW Health Department, telephone (02) 3919230 , facsimile (02) 3919029.

David Fox,

Toxicology Unit, NSW Health Department

\section{PUBLIC HEALTH EDITORIAL STAFF}

The Bulletin's editorial advisory panel is as follows:

Dr Sue Morey, Chief Health Officer, Public Health Division, NSW Health Department; Professor Stephen Leeder, Director, Department of Community Medicine, Westmead Hospital; Professor Geoffrey Berry, Head, Department of Public Health, University of Sydney; Dr Christine Bennett, General Manager, Royal Hospital for Women; Dr Michael Frommer, Deputy Director, Epidemiology and Health Services Evaluation Branch, NSW Health Department; Ms Jane Hall, Director, Centre for Health Economics Research and Evaluation; and Mr Michael Ward, Manager, Health Promotion Unit.

The editor is Dr George Rubin, Director, Epidemiology and Health Services Evaluation Branch, NSW Health Department.

The Bulletin aims to provide its readers with population health data and information to motivate effective public health action. Articles, news and comments should be 1,000 words or less in length and include the key points to be made in the first paragraph. Please submit items in hard copy and on diskette, preferably using WordPerfect 5.1, to the editor, Public Health Bulletin, Locked Mail Bag 961, North Sydney 2059. Facsimile (02) 3919232.

Design - Health Public Affairs Unit, NSW Health Department. Suggestions for improving the content and format of the Bulletin are most welcome.

Please contact your local Public Health Unit to obtain copies of the NSW Public Health Bulletin. 